\title{
Visible and invisible trauma: locating AIDS within a gendered framework in Darrell James Roodt's Yesterday
}

\section{$\underline{\text { Abstract: }}$}

Darrell James Roodt's Academy Award Nominated 2006 movie Yesterday explores how problematic gender dynamics in contemporary South Africa can influence the ways in which the issue of HIV/AIDS is perceived and dealt with socially. The film portrays the complex relationship between HIV/AIDS and identity as one that is both personal and public. Through the dramatisation of a couple's experience of living with HIV/AIDS, Roodt's film considers a way in which the epidemic can be structured - through the framework of a gendered narrative. The film's portrayal of Yesterday's journey underlines how this narrative is filled with silences, a fear to disclose, and the blaming and punishment of the female as a scapegoat for HIV/AIDS.

Key words: HIV, AIDS, trauma, gender, Yesterday, film, South Africa 


\section{$\underline{\text { Visible and Invisible Trauma }}$}

The discussion of HIV/AIDS in South Africa is one that is often connected to the topics of gender dynamics, sex, and race. The inequalities that exist in relation to these issues are regularly found to be located within the center of critical considerations of the epidemic. However, these concerns are not only ones that are prevalent in South Africa. In the United States, such on-going concerns relating to the epidemic recently led to a Presidential Memorandum - 'Establishing a Working Group on the Intersection of HIV/AIDS, Violence Against Women and Girls, and Gender-related Health Disparities' (Obama 2012). The working group shows an effort by those in power to tackle the inequalities at the heart of the epidemic. The memorandum notes that 'Gender based violence continues to be an underreported, common problem that, if ignored, increases risks for HIV and may prevent women and girls from seeking prevention, treatment, and health services' (Obama 2012). This underlines how problematic power dynamics perpetuates gender based violence and how the silences surrounding the topic act to keep women in a vulnerable position.

'Of the total estimated number of women living with diagnosed HIV at the end of 2013 [in the United States], 61\% $(137,504)$ were African American' (Centers for Disease Control and Prevention 2016). This statistic highlights how black females are most at risk in comparison to women of other ethnicities. 'Around 1 in 4 people living with HIV in the United States are women' and '[m]ost new HIV diagnoses in women are attributed to heterosexual sex' (Centers for Disease Control and Prevention 2016). The relationship between gender, sex, and HIV/AIDS here comes into play. 'Women's heightened mortality from AIDS reflects both their greater biological risks of infection during sex, as well as their systematic disempowerment within sexual relationships' (Higgins et al 2010 cited in Genorimus and Snow 2013, 23). ${ }^{1}$

\footnotetext{
${ }^{1}$ Higgins et al also discuss how women were initially invisible in terms of the discussion of HIV/AIDS.
} 
In the context of South Africa, people of all ages continue to contend with the epidemic of HIV/AIDS. ${ }^{2}$ In 2012, the UNAIDS World AIDS Day Report noted that 'South Africa scaled up its treatment services' (17) which has led to a positive 'reduction in new HIV infections' (4). However, the country's continued high rates of infection underscore how the issue of HIV/AIDS is not an uncommon one. The frightening familiarity which people in South Africa have with HIV/AIDS may at first suggest that a discussion of the topic would not raise a conflict in language. However, the social conversation concerning HIV/AIDS in the country continues to be plagued with silences as many struggle to find a suitable narrative to discuss the epidemic in light of social stigma. In relation to the discussion of HIV/AIDS, the issue of denial and disclosure can be connected to this examination of private/public, visible/invisible trauma. By tackling prominent and challenging social issues, exploring competing beliefs in relation to HIV/AIDS, and the fear of disclosure, the efforts of creative mediums such as writing and film help to form a bridge between the unimaginable and the familiar, assisting in the articulation of traumatic experiences.

South African Constitutional Court Justice, Edwin Cameron, provides an 'intensely personal account of survival' (Witness to Aids 2013) along with a literary and socially centred definition of AIDS in Witness to AIDS:

AIDS is mouth and tongue and scar and nerve and eye and brain and skin and turn and gut. AIDS is smell and feel - of sweat and grime and snot and breath and bowel and secretion, discharge, pus, putrescence, disintegration, excrement, waste. Human waste. AIDS is feeling - painful sharp tingling burning heavy dull weakening

\footnotetext{
'Virtually invisible in the earliest phases of the US epidemic [...] Over time, greater clinical understanding of HIV in women [...] helped make HIV-positive women visible'.

See: Jenny A. Higgins, Susie Hoffman, and Shari L. Dworkin, 'Rethinking gender, heterosexual men, and women's vulnerability to HIV/AIDS', American Journal of Public Health, 2010, 110:3, 435-45 (http://www.ncbi.nlm.nih.gov/pmc/articles/PMC2820057/) accessed: 25 June 2016.

2 AIDS stands for 'Acquired Immune Deficiency Syndrome' and describes the 'collection of illnesses' caused by HIV during the advanced stages of a HIV infection (Terrence Higgins Trust 2014).

HIV stands for 'Human Immunodeficiency Virus. 'Immunodeficiency' refers to how this virus weakens a person's immune system, the part of the body that fights off diseases' (Terrence Higgins Trust 2014).
} 
wasting enervating diminishing destroying bereaving. AIDS is fear. It is breathless and nameless [...] AIDS is a metaphor. It is a threat a tragedy a blight a blot a scar a stain a plague a scourge a pestilence a demon killer rampant rampaging murderer. It is made moral. It is condemnation deterrence retribution punishment, a sin a lesson a curse a rebuke judgment. It is a disease $(2005,42)$.

The continual listing of bodily organs, fluids, and emotions throughout Cameron's definition of AIDS underscores an individual's feeling of being overwhelmed and consumed by the syndrome. The lack of punctuation acts to merge all these bodily functions and sensations together, forming an image of an individual who has lost all of his or her identity, causing their sense of self to become defined by AIDS. The connection between AIDS and 'human waste' points to the experience of being unjustly persecuted and excluded from society. This is further emphasised by the words 'diminishing', 'destroying' and 'bereaving'. Cameron then moves from externalising AIDS and considering its physical effects to focusing on how the syndrome is internalised, 'AIDS is fear'.

By stating that 'AIDS is a metaphor', 'made moral' and linked to 'punishment', Cameron points to the differing problematic social and cultural understandings of the syndrome. AIDS is also described as 'nameless', referring to how many individuals can suffer and die without ever knowing that they have AIDS. The refusal to get tested perpetuates the blanket of silence that shrouds the epidemic. By referring to AIDS as a 'demon killer' and associating the condition with 'a sin a lesson a curse', Cameron refers to notions of witchcraft which some believe to be the source of AIDS. The word 'sin' also associates the condition with religious connotations. The connection made here between the syndrome and a 'sin' further causes individuals to feel ashamed and afraid to disclose information regarding their condition for fear of social exclusion and mistreatment. Cameron's definition thus touches upon some of the most significant topics concerning the discussion of the condition. 


\section{Tackling HIV/AIDS in South Africa}

Not long after the collapse of apartheid, plans for a "national AIDS strategy for the new South Africa' emerged (Gumede, 2007, 191). However, 'by early 1996 [...] money that was allocated to the health department remained unspent as the AIDS plan was buried by competing priorities in a health system in transition' (Ibid). Moreover, as criticism arose surrounding the amount of money spent on Mbongeni Ngema's AIDS musical Sarafina II, '[o]pposition parties, the media and many NGOs unleashed a barrage of attacks on [Thabo Mbeki, the then] health minister, who withdrew into a defensive shell' (Ibid). Mbeki's later controversial support for Verodine as a cure for AIDS (which researchers later revealed to contain 'dimethylformamide, a toxic industrial solvent used in dry-cleaning') (Ibid, 193) and his belief that 'pharmaceutical companies were greatly inflating the AIDS threat in order to exploit developing markets' (Ibid, 197) soon led him to question whether HIV caused AIDS and whether the virus was sexually transmitted' (Ibid).

During his presidency at an address at the opening session of the thirteenth International AIDS Conference in Durban on 9 July 2000, Mbeki referenced a previous report published by the World Health Organisation which stated that 'the world's biggest killer and the greatest cause of ill health and suffering across the globe is [...] extreme poverty' (47). Mbeki invoked the latter statement by way of questioning whether 'safe sex, condoms and antiretroviral drugs [are] a sufficient response to the health catastrophe [South Africa currently] face[s]?' (Ibid, 50-51). Mbeki answers this question by arguing that greater detailed analysis from a wide range of scientists needs to be gathered in order for the government to 'better [...] understand the essence of what would constitute a comprehensive response [to HIV/AIDS] in a context such as [South Africa] which is characterised by [...] high levels of poverty and disease' (Ibid, 52). Mbeki's reluctance to acknowledge that the most effective way of 
combating the country's health epidemic is in line with the scientifically proven connection between HIV and AIDS has unsurprisingly attracted criticism.

Before becoming President in 2009, Jacob Zuma also received criticism concerning his attitude towards the AIDS epidemic. In 2006, Zuma was accused of 'sexually assaulting a HIV positive woman. He denied the charge and won his trial, during which he stated that he had consensual sex with the woman and showered afterward to reduce his risk for being infected with HIV' (Kalichman, 2009, 121). Zuma's engagement in non-protected sex led 'health campaigners [to] say his evidence during his trial has undermined years of promoting safe sex' (The Guardian, 2006).

Since anti-retroviral drugs were made available to the public health care sector in 2004, dramatic improvements have been made in the fight against AIDS in South Africa (IRIN 2013). Growing pressure from the Treatment Action Campaign (TAC) on the government to make changes to their policies regarding HIV/AIDS treatment in the preceding 10 years helped to draw attention to the issue. The TAC (1998) called for the 'government to develop a comprehensive and affordable treatment plan for all people living with HIV/AIDS'. The TAC used a variety of strategies to pressure the government to review its policies. These included press conferences, written communication, and publicised fasting. The TAC requested an apology and retraction when 'untrue and seriously defamatory' (2004) statements were published by the African National Congress in Volume 4 No 50 of ANC Today.

Between 2009 and 2011, Zuma's presidency saw an impressive increase in the level of access for HIV management rising to seventy five per cent (AVERTing HIV and AIDS 2013a). The results reveal a direct approach taken by the government to help try and tackle the epidemic. In October 2012, the number of people receiving treatment rose to eighty per cent (AVERTing HIV and AIDS 2013a). These results are all the more gratifying in light of the country's 
previous hesitancy to provide free anti-retroviral treatment to all those who needed it. However, negative social attitudes towards the condition continues. The topic of AIDS is often seen as taboo in South Africa with many people refusing to discuss the condition publicly (See Wegerif 2014). Prejudice towards people living with AIDS fuels the refusal to get tested, causing disclosure to become a major concern in the critical discussion of AIDS.

Darrell James Roodt was adamant in his belief that 'it was essential to make [Yesterday] in Zulu as that is where the truth is' (Yesterday the movie 2013). The importance of context is further emphasised by Roodt's decision to set the film in the province of KwaZulu-Natal, which has the highest levels of recorded HIV infection rates in the country (AVERTing HIV and AIDS 2013b). 'In the most severely affected province of KwaZuluNatal, 4 out of 10 women giving birth tested positive for HIV' (Oppenheimer and Bayer 2007, 5). The Director also chooses to focus on a female protagonist living with the condition, mirroring statistics which reveal that 'rural black women [are the] population group most affected by the disease' (Treffry-Goatley 2012). Patriarchal dynamics continues to influence the relationship between gender and HIV/AIDS in South Africa. The dominance and authority of the male in many familial households has affected the way in which HIV/AIDS has been framed and understood in the country.

Locating AIDS within a gendered framework in Yesterday

Roodt's Academy Award Nominated 2006 movie Yesterday dramatises how problematic gender dynamics in contemporary South Africa can influence the way HIV/AIDS is perceived and dealt with. The audience follows the life of Yesterday, played by Leleti Khumalo, as she struggles to care for her AIDS stricken husband, John, while dealing with her own knowledge of living with HIV. Through the portrayal of the couple's experience of living with HIV/AIDS, Roodt's film considers a way in which the epidemic can be structured - through a gendered narrative. 
This narrative is shown to be filled with silences which invite deeper consideration into the fear of disclosure, and point to the blaming and punishment of the female as a scapegoat for HIV/AIDS.

A unique aspect of film which distinguishes it from many other mediums of expression is the use of moving images to dramatise change. As the story being told is made visible, the depiction of characters and settings are shown to the audience. In contrast, when reading a story, the text paints a written picture of how people or a place would appear, but it is up to the individual reader to imagine for themselves how these appear in their own mind. With film, the audience has no choice but to digest the depictions on screen. The latter creates an immediate relationship between the audience and the images in front of them. It is this immediacy which involves the audience with the story being played out on screen, and which helps to form a connection between them and the characters in the film. If through the medium of film the audience is somewhat located as witnesses to the events which unfold on screen, the position of the viewer becomes one that is more involved and more active than that of a passive audience member.

The relationship between Yesterday and John is initially portrayed as traditional in regards to the gender roles they play in their marriage, evident from the almost all female village where the women stay home to care for their children while their husbands work away. It is never explicitly stated how John contracts HIV. However, the audience can assume that it was not through sexual relations with his wife. Yesterday spends her day working and raising their daughter, Beauty, with no suggestion of male friends. The choice by Roodt to depict Yesterday as presumably having contracted HIV from her migrant worker husband reflects realistic statistics of infection, as higher levels of HIV infection can be found in 'communities of the mobile' (Zuma et al 2013, 22). Their loving relationship then becomes tainted by violence 
after John violently beats his wife in a corridor after she tells him that she has contracted HIV and that he too must be tested. John's reaction raises questions concerning the blaming of women for the spread of HIV in South Africa.

The lack of dialogue in Yesterday means that not everything is openly discussed. Rather, many points are subtly implied, pointing to the social tendency to repress the subject of HIV/AIDS. By analysing Yesterday and its engagement with post-apartheid social concerns, the topic of HIV/AIDS is not confined to a dark corner but debated in the public sphere. It helps to dispel the shame and stigma attached to the discussion of HIV/AIDS, creating a space which helps to grapple with the epidemic. Yesterday begins with the sounds of crickets chirping, soon followed by the introduction of slow playing instruments which form a steady rhythm. The audience is informed that the season is Ehlobo (summer). However, the expectation to see green trees and flowers in full bloom is not fulfilled.

The slow and wordless introduction of Roodt's film sets a tone of trepidation whilst the introduction of a man's faint singing conjures up an air of sadness. The initial scene is one of pathetic fallacy; the camera captures a vacant land surrounded by wired fences and dead trees. The depiction of barrenness and seeming separation from society portrays the rural KwaZulu-Natal as lifeless. The audience is thrown into a dead land where dusty grounds and sandy rocks portray a landscape which craves water and life. The feeling of death pervades the scene, pointing to later issues which soon become central to the film. Whilst the bright sun helps to clearly depict the season of summer, a lack of joy is portrayed through the absence of people and buildings. The loneliness that is shown in the introductory scene is also revealing of the emotional turmoil which Yesterday has to undergo throughout the film. As the musical rhythm gets faster, a man's incoherent singing voice is heard accompanying the instrumental music. It is not until 2.30 minutes into the start of the film that the outlines of two people slowly come 
into view. ${ }^{3}$ The long pause before any people come into view means the audience has no choice but to concentrate on the lifeless landscape and the far away mountains in the distance, pointing to the feeling of being caught between hope and hopelessness, a tension which pervades the film.

The audience sees Yesterday who we soon learn is from Rooihoek and her daughter, Beauty, walking towards the camera. Their visibility is the first injection of life in the movie. This is not the only time that Yesterday is filmed walking a long distance. Throughout the film, a lack of money to take a taxi ride to the clinic means that Yesterday has no choice but to walk for miles in an effort to be seen by a doctor at the nearest clinic. She informs passers by that she had been walking for two hours. Her daughter, Beauty, also struggles with the distance and tells her mother that she wants to be a bird so that they could fly to the clinic (00.04.15). Long walks to the clinic highlight the lack of health care services in rural areas, which in turn impacts on Yesterday's access to knowledge, protection and medicine. The lack of healthcare services surrounding Yesterday's village affects the progression of her condition significantly. Having been turned away repeatedly at the clinic due to the long queue of people, a fellow villager tells her 'it is best to come early. Before the sun' (00.08.44). The audience witnesses Yesterday's deteriorating health through signifiers such as coughing and weight loss. Her declining temperature also leads her to wear a warm gown and hat to bed, even in the heat of summer (00.09.39). These indicators of increasingly diminishing health also point to the passing of time in the film. When Yesterday is finally able to see a doctor, the audience learns that she has been suffering from her cough since before Christmas time (00.30.20). The affect which the condition has on the body is emphasised on screen as Beauty finds her mother passed out

\footnotetext{
${ }^{3}$ Darrell James Roodt, Yesterday, HBO Films (2006). [Subsequent references are to this edition].
} 
in their doorway (00.22.39). As her body declines, the growing loss of hope concerning her health is contrasted with Yesterday's continued strength to care for her family.

The social stigma which hovers over the discussion of AIDS is evident throughout Roodt's movie. Even during the scene where the audience learns that Yesterday has HIV, this is not referred to outright (Roodt 2006) (00.38.00). Later, when Yesterday's friend asks her why she needs to travel to Johannesburg to see John so urgently, Yesterday replies, 'I cannot say' (00.47.20). Yesterday feels ashamed to tell her secret and chooses to keep hold of her private pain. However, the language Yesterday uses does not suggest an unwillingness to disclose, but rather an inability to speak of her pain. Yesterday's silence may be rooted in her feeling unable to find sufficient words to encompass her emotions and thoughts. In this moment, the capability of language is put to the test as Yesterday fails to the find a way to communicate her turmoil. Referring back to Cameron's definition of AIDS, it may also be the condition itself which overwhelms Yesterday, causing her to remain quiet when faced with questions.

The sporadic silences employed by characters throughout the film, which point to an avoidance of the language of HIV/AIDS is contrasted with the film's explicit depictions of the AIDS stricken body. In her chapter on 'Silent bodies and dissident vernaculars: representations of the body in South African fiction and film', Attree (2015) notes that 'Yesterday is unusual in its graphic depiction of the suffering (herterosexual) male body' (188). Attree (2015) continues to state, '[t]he film provides a unique counterpoint to written literature, which rarely focuses on either the physical or rural experience of HIV/AIDS, exposing the silent bodies of the rural poor on screen to a much larger audience' (194). The portrayal of Yesterday's weakening body and John's deterioration locates audiences as passive witnesses to the events unfolding before them. Commenting on John's decline, Attree (2015) similarly notes, '[h]e suffers on screen for us all to watch' (195). In this way, audiences are situated in a position in which we gaze upon the 
individual, much like that of his fellow villagers. For those watching the film, John's ill-health is a visible one. However, for the other villagers, whilst news of John's condition becomes public, Yesterday makes an effort to keep her husband shielded from prying eyes, the villagers note that they had not seen John for days (00.59.55). In addition, Yesterday cares for her husband at home until he is shunned by villagers and forced to move into a homemade hospital outside the village.

The sense of secrecy that surrounds the discussion of HIV/AIDS is fuelled by fears of social alienation. When the teacher asks Yesterday if there is something wrong, she refuses to say anything (00.47.40). However, her silence reveals that something is indeed the matter and that the problem she has to deal with is something she feels must be kept a secret. HIV 'remains hidden, even in the words spoken on screen, just as it lies hidden in the body, until it develops into full blown AIDS' (Attree 2015, 196). Yesterday's refusal to discuss her condition with her best friend may lie in her fear that to do so would risk losing her only genuine friendship in the village. 'The silences, the secrecy, are all part of the story of HIV in South Africa' (Attree 2015, 196). Yesterday does not want her friend to perceive her differently because she has HIV, something she fears may happen. It is therefore not only social stigma which causes many to suppress the discussion of HIV/AIDS, but also the literal isolation from others. The tendency to blame females for the spread of HIV/AIDS may also be a reason for Yesterday's silence. Her refusal to discuss the subject is also at this point an attempt by Yesterday to keep her trauma private and invisible from those around her.

Before Yesterday discovers she is living with HIV, Yesterday's best friend (and village teacher) suggests that the tiredness and feverishness she is feeling may be due to diabetes (00.27.00). Yesterday's friend offers her a logical possible explanation for her failing health. The teacher is thus portrayed in the film as a mouthpiece for science and medicine whilst the other villagers represent a belief in cultural tradition. The two opposing viewpoints 
come into conflict when it becomes public knowledge that Yesterday is living with HIV. The teacher tries to explain to the villagers that the social alienation of Yesterday and her husband, John Khumalo, is unnecessary as HIV can only be 'transmitted' via blood (01.08.00). The women ask what the teacher means by the term 'transmitted' and refuse to accept the facts about HIV. The unfamiliar terminology hinders the conversation between the women and the teacher. Language is once more portrayed as a barrier, preventing people from being able to discuss and understand the condition, fuelling the division between the villagers. The alien terminology increases the distance between the teacher and the women, and heightens their refusal to try and understand her arguments. The irony of this scene is that it takes place in a setting of knowledge - a classroom, and yet the information being imparted is not listened to. The women's reluctance to accept a different understanding of HIV/AIDS to what they are used to hearing emphasises the need for a greater education system regarding the epidemic. The teacher's unsuccessful attempts to explain the facts of the condition underline how such knowledge is perceived amongst the villagers as a challenge to traditional and cultural beliefs.

By standing by the belief that John's condition places the entire village at risk, the women are able to structure their arguments within a narrative frame that they are familiar with and able to maintain control over. Consequently, when discussing John and his condition, the villagers cruelly state, 'he must go' (01.10.00). The women then gather to see Yesterday and her husband leave, a scene which depicts the villagers gazing on the couple as a spectacle (01.15.00). By exiling John, the villagers make an effort to perceive the issue of HIV/AIDS not as an epidemic or a wider problem which must be tackled, but as a condition which is located specifically to an individual and particular family. By doing so, the villagers are able to seemingly contain the condition and purge their village of the virus. The villagers' rejection of science and the knowledge of the teacher can be interpreted as an effort to sustain their cultural beliefs and traditions in the community. In this way, their traditional views concerning 
the cause and treatment of the condition allow the villagers to use individuals as scapegoats for HIV/AIDS.

When Yesterday later informs her friend that she has been living with HIV for many months, her friend wonders why she chose to keep the information secret. In response, Yesterday recalls the story of a woman from Bergville who was so renowned for her intellect that her fellow villagers pulled together enough money to send the girl to university in Johannesburg. However, on a visit home, the girl disclosed the news that she had AIDS and was stoned to death (1.06.22). The news of the young girl's condition altered her from being considered as an individual who is smart and hard working to one whose identity is solely formed by her illness. The shame and stigma attached to AIDS causes the condition to be viewed as a source of evil and leads to the killing of the girl by way of supposedly cleansing the village. However, in doing so, another ordeal of death is created. The story points to how AIDS is not simply viewed as impacting the individual living with the condition, but is perceived as a condition which also has perilous consequences for those around the individual too. It is this perception of AIDS as a communal trauma which gives the villagers a sense of legitimacy to control the situation and therefore supposedly justifies their punishment of her. Consequently, Yesterday favours silence as a form of protection against social backlash.

On her third visit to the clinic (ixhaphozi) in Kromdraai, Yesterday meets with a white Afrikaans female doctor who after mentioning the limited number of doctors available in the area goes on to run various tests on Yesterday. The camera zooms in on Yesterday's face as she feels the sharp pain of the needle on receiving a blood test. The audience later learns of Yesterday's surprise on discovering that the doctor she had been waiting to see was a woman. Yesterday's shock points to how gender stereotypes play a part in social perceptions of work roles too. A little into the first half of the film, the movie suggests that Yesterday does in fact 
realise she has HIV, however it is never openly discussed or mentioned, highlighting the suppression of HIV/AIDS as taboo.

After receiving the news that she has contracted HIV, Yesterday asks the doctor 'am I going to stop living? (00.40.18). The doctor remains silent in response to this direct question, possibly revealing of her efforts to not frighten Yesterday. The close up camera shots of the two women who are sat silently facing each other highlight the emotional struggle which they are both experiencing. The doctor's avoidance of the terms HIV and AIDS when talking to Yesterday may be rooted in an effort to not cause increased fear or additional stress for her patient due to the negative connotations which the terms often have. Rather, the doctor focuses on the condition as something separate from the unjust social undertones connected with HIV.

However, by avoiding the use of these terms, the doctor may be accused of inadvertently fuelling the stigma surrounding the condition through continuing the silence which hovers over the discussion of the terms HIV and AIDS. 'The Stigma Index Survey revealed that although South Africa has much lower levels of HIV stigma than other African countries, women continue to be disproportionately affected, particularly in relation to sexual and reproductive health' (AVERTing HIV and AIDS 2016). As a result, the conscious suppression of these terms in daily conversation by the doctor and other characters in the film in an effort to protect individuals from experiencing social stigma, in some ways causes the explicit discussion of the condition to seem more taboo.

It is not until over an hour into the film that the condition is referred to as 'the virus. HIV' (01.06.04) and Yesterday admits that both she and her husband are infected. Yesterday 
tells her friend, 'I have it too' (1.06.14). At this moment, the teacher's hand held lamp goes out, causing the scene to become literally darkened by the news. Her statement is a significant moment of disclosure. As Yesterday takes ownership of her condition, she also takes possession of her own identity, refusing to let it become shaped by those around her.

Due to South Africa's continued unjust gender hierarchy in which women have come to often be reliant on the male, for a woman to disclose her HIV/AIDS condition would mean risking the loss of income and security. Public knowledge of an individual's HIV/AIDS condition thus has the potential to impact greatly on the viability of a relationship. The perception of females as inferior in status in comparison to males leads women to be viewed as commodities, particularly in regards to sexual relations. The blaming of the female for the spread of HIV/AIDS therefore becomes a common narrative used to frame the epidemic. Tackling the on-going gender inequality still existent in South Africa, Daniella Coetzee in 'South African education and the ideology of patriarchy', (2001, 300) notes that 'against the background of legislation aimed at rooting out gender discrimination in this country, it is an open question why attempts at transformation have only [resulted] in the accommodation of women on the surface. The answer to this question appears to be connected to the ideological status of the [system] of patriarchy'.

Considering 'Gender Issues in HIV/AIDS Epidemiology in Sub-Saharan Africa', Ben E. Wodi $(2005,2-3)$ notes 'in the era of HIV/AIDS, this power imbalance between the sexes carries a new sense of urgency. Women have become especially susceptible to the disease as a result of their limited power in sexual encounters'. Catherine Albertyn (2003) in 'Contesting Democracy: HIV/AIDS and the Achievement of Gender Equality in South Africa' also explores the relationship between gender inequality in South Africa and HIV/AIDS. Albertyn (2003, 598) argues that gender inequality is one of the primary causes for the spread of HIV, which 
is perpetuating the high rates of infection in South Africa. The problematic narrative of gender inequality is here shown to be further complicating the issue of AIDS in South Africa. Albertyn (2003, 597-8) comments that 'poverty underpins women's vulnerability to HIV/AIDS because, for women in Africa, poverty often means that having sex in exchange for shelter, food, or other basic necessities can become a means for survival'. Relationships here become employed as transactions between individuals where power over the other lies in economic control.

The latter unjustly locates women as inferior, situating them as easy scapegoats for the rapid spread of HIV/AIDS. Yesterday dramatises the strain which HIV can have on a relationship as Yesterday's husband violently beats his wife once she tells him she has HIV. John's reaction is one of immediate anger rooted in an effort to deflect and blame the cause of his pain on to his wife. John's inability to control what is happening to his own body arguably leads him to dominate his wife's body. John's inability to absorb the information regarding his condition manifests itself in a violent beating of his spouse. In addition, by hitting his wife, John overtly implies that either Yesterday is lying or that it was from her that he contracted HIV. In this way, John tries to justify his violent actions by legitimising his behaviour as an act of punishment.

The violent scene occurs in the dim lit corridor outside John's Manager's office. The dark walls and small-enclosed space creates a suffocating atmosphere, forming a pressure cooker of emotion. The barred windows of the building emphasise the prison-like surroundings. During this scene, the camera shot is taken from in front of the Manager's office desk and the audience sees Yesterday's husband beating his wife through the office window (00.49.40). Throughout the film so far, the close camera shots of the significant emotional 
moments in Yesterday's life have allowed the audience to feel a closer connection to the movie's protagonist, enabling the audience to share the experiences she has undergone. In contrast, during the scene in which John violently attacks Yesterday, the audience is situated on the outskirts of the event as viewers are located as passive witnesses to the violence which unfolds before them. The domestic abuse here becomes public and visible.

The Manager who is sat in the office turns round on hearing the commotion but then quickly turns away and carries on as normal. This enrages the audience as the Manager is a witness to the event and yet refuses to help. The Manager's reluctance to get involved with the couple's argument may lie in his fear of getting dragged into the abuse which occurs. Nevertheless, his position of authority over John in the workplace would be enough to help stop the violence from occurring further. Instead, the Manager briefly shakes his head but does nothing to help the victimised woman behind him. The Manager here chooses to turn his back to the event occurring behind him. His decision to ignore the beating perpetuates the violence further. His behaviour points to existing ideas concerning patriarchy and the dynamics of power in connection to gender dynamics in South Africa. The Manager's relaxed reaction towards Yesterday's mistreatment behind him creates a sense of normalisation surrounding the issue of gendered violence.

However, the audience are also unable to help Yesterday as viewers are located in the same room as the Manager and are made to watch the scene from behind the window. Images of the beating on screen become blurred as the sound cuts out. The lack of sympathy from the Manager makes the scene even more problematic as the event shows the victimization of one woman by two men. While Yesterday is physically abused by John, the Manager's choice to ignore the incident leads to Yesterday being abused further. By dramatising the physical 
abuse of Yesterday, is Roodt trying to make the audience consider how easy it is to dismiss and ignore traumas which we do not have to witness, and how difficult it is to experience the impact of being a witness?

By choosing to locate the violent scene behind the Manager's office, there is a feeling that the violence is pushed into the distance. But one may interpret this scene as a moment where private trauma becomes public. However, the Manager's choice to allow the violence to continue is simultaneously a decision to turn Yesterday's visible trauma into an invisible one, turning the now public trauma into a private one. The audience is also unable to hear a lot of the dialogue between Yesterday and John during this scene. There is also background music throughout the violent episode. The scene is thus also silenced literally. Therefore, the audience is made partially blind and deaf to the events that unfold. This further locates the audience with the Manager who chooses not to look or listen to the violent scene behind him.

John's employment of extreme physical violence may also be read as a refusal to confront his trauma, rather choosing to divert his anger and attention towards blaming his spouse. A regularly cited scholar in discussions regarding trauma studies, Saul Friedlander in 'Trauma, Transference and Working Through', defines 'working through' trauma as a process which tries to 'keep some measure of balance between confronting the emotion recurrently breaking through the 'protective shield' and numbness that protects this very shield' $(1992,51)$. By abusing his wife, John may feel a perverse sense of power and control over the situation. His actions may be a desperate attempt to manage the shock and frustration he experiences. It may be argued that Yesterday's news transforms John's suspicions of his failing health into a reality. The news from his wife thus removes the comfort of denial which John was previously living in. John later admits to his wife that his violent reaction was driven by denial. John's initial stage of a seemingly healthy appearance meant that he could for a short period of time 
continue to live in a state of comforting ignorance. John confesses, 'I did not want to believe what you told me. I did not. But it kept playing over in my mind. Over and over, driving me crazy' (00.58.03). John's admission is a good example of Cathy Caruth's (2003, 193) explanation of how 'trauma is not assimilated or experienced fully at the time'. A leading scholar on the critical and theoretical discussion of trauma studies, Caruth goes on to comment that trauma is experience 'belatedly, in its repeated possession of the one who experiences it' $(2003,193)$.

On his return home, John waits outside his familial home and is so weak he is unable to properly raise his hand to wave at Yesterday. Shivering in the cold, John's skin is grey and he has sores on his face. The weight loss and frailty of his body is evident to the audience. In this scene, AIDS is clearly visible. Sat in a dark and dimly lit dining room, John tells Yesterday about his failing health whilst working in the mines. He recalls the embarrassment of suffering from uncontrollable diarrhoea every five minutes, 'I messed in my pants, over and over' (00.56.43), 'I stank like an animal' (00.57.33). As the condition became visible to those around him, the noticeable symptoms of John's deterioration force him to confront the reality of his condition, leading him to return home to his village. The loss of control over his body and the disgusted reaction of his colleagues cause John to feel embarrassed at work. His weakening body is here paralleled by his feelings of loss of masculinity.

\section{$\underline{\text { Conclusion }}$}

After burying John and visiting his grave every day since winter, Yesterday decides to destroy the homemade hospital she built to help care for her dying husband (01.25.18). Her actions are a cathartic outpour of emotion. As she smashes through the scrap metal and pieces of old tile, the built up turmoil she has tried so hard to keep under control is 
unleashed on to this abandoned home. Another sense of relief comes with knowing that Yesterday's best friend agrees to take care of Beauty. Yet the audience are still left wondering about particular questions concerning the future welfare of Yesterday. It is unclear whether Yesterday will return to live in Rooihoek or whether she will be also be forced out of the village. To structure an ending which offers complete answers would cause Yesterday to lose its credibility as a critical exploration of HIV/AIDS in South Africa, transforming the film into a simplistic dramatisation of suffering and closure.

Yesterday highlights the complex and problematic relationship between HIV/AIDS and identity as something both personal and public. The social persecution towards people living with HIV/AIDS is portrayed as being rooted in a lack of understanding of how HIV/AIDS is transmitted and treated. The difficulties faced when trying to access health care treatment in the rural KwaZulu-Natal also emphasise the lack of help available to those in need. Furthermore, an examination of Roodt's motion picture underscores an effort to explore the way in which HIV/AIDS can be structured within a gendered framework, testing the limits of language and narrative to communicate and critically discuss the topic of HIV/AIDS in postapartheid South Africa. 


\section{Bibliography}

Albertyn, Catherine, 'Contesting Democracy: HIV/AIDS and the Achievement of Gender Equality in South Africa', Feminist Studies, 29:3, (2003), 595-7.

Attree, Lizzie, 'Silent bodies and dissident vernaculars: representations of the body in South African fiction and film' in Julia Gallagher (ed.) Images of Africa: Creation, Negotiation and Subversion (Manchester: Manchester University Press, 2015), pp. 188200 .

AVERTing HIV and AIDS (2013a), 'Antiretroviral treatment in South Africa' (http://www.org/aidssouthafrica.htm\#contentTable5) [accessed:

02/01/2013].

AVERTing HIV and AIDS (2013b), 'South Africa HIV and AIDS Statistics' (http://www.avert.org/southafrica-hiv-aids-statistics.htm) [accessed: 01/03/2013].

AVERTing HIV and AIDS, 'South Africa: Women still carry burden of stigma' (https://www.avert.org/news/south-africa-women-still-carry-burden-stigma) [accessed: 13/03/2016].

Cameron, Edwin, Witness to AIDS (London: I.B. Tauris, 2005).

Caruth, Cathy, 'Trauma and Experience' in Neil Levi and Michael Rothberg (eds.), The Holocaust: Theoretical Readings (Edinburgh: Edinburgh University Press, 2003), pp. 192-199.

Centers for Disease Control and Prevention, CDC 24/7: Saving Lives, Protecting People, 'HIV Among Women' (http://www.cdc.gov/hiv/group/gender/women/index.html\#refc) accessed: 24 June 2016.

Coetzee, Daniella, 'South African education and the ideology of patriarchy', South African Journal of Education, 21:4 (2001), 300-304.

Cvetkovich, Ann, 'Legacies of Trauma, Legacies of Activism: ACT UP's lesbians' in David L. Eng, David Kazanjian (eds.), Loss: the politics of mourning (California: University of California Press, 2003), pp. 427-457. 
Friedlander, Saul, 'Trauma, Transference and Working Through', History and Memory 4:1 (1992), 39-59.

Geronimus, Arline T., and Rachel C. Snow, 'The Mutability of Women's Health with Age: The Sometimes Rapid, and Often Enduring, Health Consequences of Injustice' in Marlene B. Goldman, Rebecca Troisi and Kathryn M. Rexrode (eds.), Women and Health, second edition (London: Academic Press - imprint of Elsevier, 2013), pp. 2132.

Gumede, William Mervin, Thabo Mbeki and the Battle of the Soul of the ANC (Cape Town: Zebra Press, 2007),

Griinkemeier, Ellen, Breaking the Silence: South African Representations of HIV/AIDS (Boydell and Brewer Ltd: Suffolk, 2013).

Higgins, Jenny A., Susie Hoffman, and Shari L. Dworkin, 'Rethinking gender, heterosexual men, and women's vulnerability to HIV/AIDS', American Journal of Public Health, 2010, 110:3, 435-45 (http://www.ncbi.nlm.nih.gov/pmc/articles/PMC2820057/) accessed: 25 June 2016.

'HIV/AIDS, Population Mobility and Migration in Southern Africa: Defining a Research and Policy Agenda', The Southern African Migration Project and the International Organization for Migration, June 2005 (http://www.queensu.ca/samp/migrationresources/reports/PopulationMobilityReport.pdf) [accessed: 03/04/2013].

IRIN: humanitarian news and analysis, 'South Africa: A timeline of HIV/AIDS activism' (http://www.irinnews.org/report/93877/south-africa-a-timeline-of-hiv-aids-activism) [accessed: 23/06/2013].

Kalichman, Seth, Denying AIDS: Conspiracy Theories, Pseudoscience, and Human Tragedy (New York: Copernicus Books, 2009).

Mbeki, Thabo, 'Extreme poverty is the world's biggest killer', Address at the opening session of the 13th International AIDS Conference, Durban, 9 July 2000 in Thabo Mbeki, Africa Define Yourself: Thabo Mbeki (Cape Town: Tafelberg Publishers), pp. 46-52.

Obama, Barack, 'Presidential Memorandum - Establishing a Working Group on the Intersection of HIV/AIDS, Violence Against Women and Girls, and Gender-related Health Disparities', The White House: Office of the Press Secretary, March 302012 (https://www.whitehouse.gov/the-press-office/2012/03/30/presidential-memorandumestablishing-working-group-intersection-hivaids-) accessed: June 242016. 
Oppenheimer, Gerald M., and Ronald Bayer, Shattered Dreams: An Oral History of the South African AIDS Epidemic (Oxford: Oxford University Press, 2007).

Roodt, Darrell James, Yesterday (South Africa: HBO Films, 2006).

Terrence Higgins Trust, 'What are HIV and AIDS?' (http://www.tht.org.uk/sexual-health/AboutHIV/What-are-HIV-and-AIDS qm) [accessed: 07/05/2014].

The Guardian, 'Jacob Zuma Cleared of Rape', 8 May 2006

(www.guardian.co.uk/world/2006/may/08/aids.southafrica) [accessed:

13/04/2013].

Treatment Action Campaign (1998) HIV/AIDS TREATMENT ACTION CAMPAIGN 10 DECEMBER 1998 - DAY OF ACTION INTERNATIONAL HUMAN RIGHTS DAY. Available at: http://www.tac.org.za/news/hivaids-treatment-action-campaign-10december-1998-dayaction-international-human-rights-day (Accessed: 21.10.2015)

Treatment Action Campaign (2005) LETTER FROM TAC TO ANC - 21 December 2004. (http://www.tac.org.za/news/letter-tac-anc) [accessed: 21.10.2015].

Treffry-Goatley, Astrid, 'HIV/AIDS in Post-apartheid South African Cinema' (http://www.africacentre.ac.za/Portals/O/News\%20Archive/SA\%20AIDS\%20Conf\%202011/0 1\%/020AstridT-G.pdf) [accessed: 01/04/2012].

Wegerif, Maryatta, 'The Never-Ending Fight against Taboos and Death in South Africa' (http://www.wegerif.de/blog/2011/09/01/the-never-ending-fight-against-taboos-anddeathin-south-africa/) [accessed: 08/04/2014].

Witness to Aids, 'WITNESS TO AIDS, WITH TWO CHAPTERS CO-AUTHORED BY NATHAN GEFFEN' (http://www.witnesstoaids.com/) 2013 [accessed: 28/07/2016].

Wodi, Ben E., 'Gender Issues in HIV/AIDS Epidemiology in Sub-Saharan Africa', Wagadu, Vol. 2 (Summer 2005), online article, pp. 1-10 (http://webhost1.cortland.edu/wpcontent/uploads/2014/02/wodi.pdf) [accessed: 28/07/2016].

'Yesterday the movie: About the Production' (http://www.yesterdaythemovie.co.za/about production.asp) [accessed: 13/04/2013]. 
Zuma, K., et al., 'Risk Factors for HIV Infection Among Women in Carletonville, South Africa: Migration, Demography and Sexually Transmitted Diseases', International Journal of STD and AIDS, 14 (2003): 81447. 